\title{
Approach to primary thyroid lymphoma: case series
}

\author{
Nihan Acar ${ }^{1}$, Turan Acar ${ }^{1}$, Arzu Avcl ${ }^{2}$, Mehmet Haciyanlı ${ }^{1}$ \\ ${ }^{1}$ Clinic of General Surgery, Izmir Katip Celebi University Atatürk Training and Research Hospital, Izmir, Turkey \\ ${ }^{2}$ Clinic of Pathology, Izmir Katip Celebi University AtatürkTraining and Research Hospital, Izmir, Turkey
}

\begin{abstract}
Primary thyroid lymphomas are rare thyroid neoplasms. Mucosa Associated Lymphoid tissue (MALT) lymphoma and diffuse large B-cell Non-Hodgkin lymphoma are the most common types. It is more common in the elderly, and especially in women. Patients usually present with a rapidly growing mass in the neck. This article aimed to present the epidemiological features, treatment and prognostic factors of thyroid lymphomas by retrospectively reviewing 4 patients with thyroid lymphoma. Four patients were treated for primary thyroid lymphoma, two of whom were women and two were men, with a mean age of $63.7(51-74)$ years. Common complaint of those patients was the sudden swelling of the neck. Two patients were diagnosed with fine needle aspiration biopsy (FNAB) and the other two patients were diagnosed with surgical excision. Chemotherapy and radiotherapy were applied to all four patients. While one patient died in the second year of follow-up, the other three patients are still being followed. Primary thyroid lymphomas are not aggressive tumors, and the most effective treatment is radiotherapy.
\end{abstract}

Keywords: Thyroid, lymphoma, MALT, non-hodgkin

Cite this article as: Acar N, Acar T, Avcı A, Hacıyanlı M. Approach to primary thyroid lymphoma: case series. Turk J Surg 2019; 35 (2): 142-145

Corresponding Author

Turan Acar

E-mail: drturanacar1982@gmail.com

Received: 13.03 .2018

Accepted: 07.05.2018

Available Online Date: 13.06.2019

@ Copyright 2019 by Turkish Surgical Society Available online at www.turkjsurg.com

DOI: $10.5578 /$ turkjsurg.4132

\section{INTRODUCTION}

Papillary thyroid carcinoma is the most common type of thyroid cancers. On the other hand, primary thyroid lymphomas (PTL) are rare tumors, 1-5\% of all thyroid neoplasms and approximately $2 \%$ of the extranodal lymphomas (1). Male to female ratio is 1:3, and it mostly occurs after the age of 50 (age range, 50-65). Thyroid lymphomas are usually associated with Hashimoto's thyroiditis and they develop on a background of chronic thyroiditis (2).

Histologically, Hodgkin or Non-Hodgkin Lymphomas may be identified. Although B-cell Non-Hodgkin Lymphoma is the most common type, T-cell lymphoma of the thyroid has also been rarely reported (3). This study aimed to present the epidemiological features, diagnosis, treatment and prognostic factors of thyroid lymphomas by retrospectively reviewing medical records of four patients with thyroid lymphoma.

\section{CASE REPORTS}

Demographics, clinicopathologic features, diagnosis and treatment methods of the patients are given in Table 1.

Two out of four patients (50\%) were female and the mean age was 63.7 (range: 5174) years. All patients complained of suddenly growing mass of the neck. In addition, there were also systemic symptoms (75\%), fever and pressure symptoms (50\%) such as respiratory distress and hoarseness. Physical examination revealed diffuse cervical lymphadenopathy (LAP) in all patients, and one patient had solid palpable thyroid nodules with irregular surface. There were no palpable lymph nodes in the rest of the systemic examinations. One patient had elevated Thyrotrophin-Stimulating Hormone (TSH) level (normal range: 0.4-3.0 ulU/mL) (hyperthyroid) and one patient had low TSH level (hypothyroid). TSH levels of the other two patients and all other laboratory parameters of all patients were normal. Thyroid ultrasound (US) was performed in all patients as an initial imaging test. US showed bilaterally heterogeneous and hyperplastic thyroid gland in all patients. Besides, all patients 
Table 1. Demographics, clinicopathologic features, diagnosis and treatment methods of the patients

\begin{tabular}{|c|c|c|c|c|}
\hline & Case 1 & Case 2 & Case 3 & Case 4 \\
\hline Sex & Male & Male & Female & Female \\
\hline Age & 74 & 68 & 62 & 51 \\
\hline $\begin{array}{l}\text { Thyroid } \\
\text { hormone levels }\end{array}$ & Hypothyroid & Euthyroid & Hyperthyroid & Euthyroid \\
\hline $\begin{array}{l}\text { Diagnostic } \\
\text { methods }\end{array}$ & FNAB & BTT & FNAB & BTT \\
\hline $\begin{array}{l}\text { Pathology } \\
\text { result }\end{array}$ & High grade lymphoma & $\begin{array}{l}\text { Papillary carcinoma + diffuse large } \\
\text { B-cell Non-Hodgkin lymphoma }\end{array}$ & $\begin{array}{c}\text { Diffuse large B-cell } \\
\text { Non-Hodgkin lymphoma }\end{array}$ & $\begin{array}{l}\text { MALT Iymphoma (developed in } \\
\text { Hashimoto thyroiditis' background) }\end{array}$ \\
\hline Stage & Stage 3 & Stage 3 & Stage 3 & Stage 1 \\
\hline Treatment & Surgical excision $+C T+R T$ & Surgical excision $+C T+R T$ & $C T+R T$ & Surgical excision $+C T+R T$ \\
\hline Mortality & Follow-up & Follow-up & Exitus & Follow-up \\
\hline
\end{tabular}

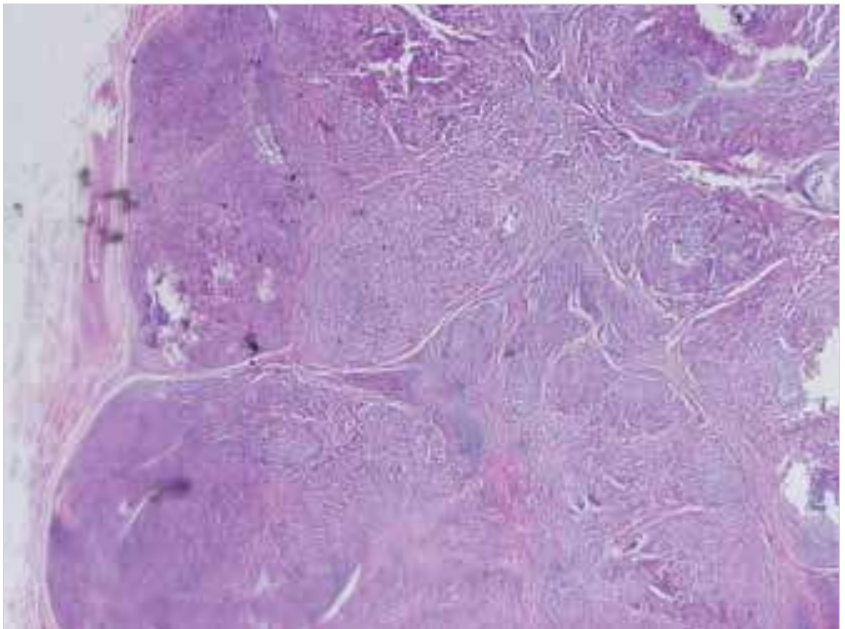

Figure 1. Diffuse atypical lymphoid infiltration and interstitial small follicles consisting of thyrocytes. X2, H\&E stain.

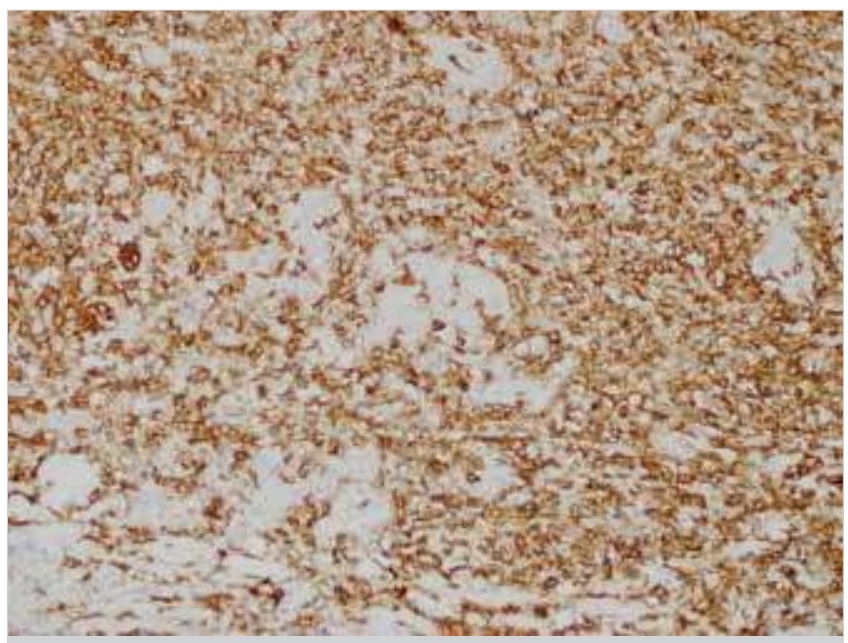

Figure 2. Diffuse large B-cell Non-Hodgkin lymphoma in CD20 positive neoplastic cells. X20. had multiple enlarged cervical lymph nodes. Fine needle aspiration biopsy (FNAB) was performed on all patients for diagnosis. However, only two of our patients could be diagnosed as thyroid lymphoma and the other two patients were non-diagnostic with FNAB. Therefore, these two patients underwent surgical excision (total thyroidectomy) and their pathological examinations were reported as primary thyroid lymphoma (Figure 1). In addition, CD 20 was positive and CD 3, CD 45 RO, BCl-6 and BCl-2 were found to be negative in immunohistochemical studies in both patients (Figure 2).

Systemic cancer screening and staging were performed with computed tomography. According to Ann-Arbor Staging System, one patient was stage 1 and the other three patients were stage 3. All patients received chemotherapy (CT) and radiotherapy (RT). One patient died in the second year of follow-up. The rest of the patients who underwent total thyroidectomy and received combined therapy $(C T+R T)$ are at the mean $46^{\text {th }}$ (range: 38-59) month of follow-up and there is no evidence of systemic or local recurrence.

Informed consent was obtained from both patients. Consents were also obtained to perform scientific studies.

\section{DISCUSSION}

PTL is a rare tumor of the thyroid and more commonly seen in middle aged-elder women. MALT lymphoma and diffuse large B-cell non-Hodgkin lymphoma are the most common types (3). In our study, the patients were also elderly, but on the contrary, gender distribution was identical.

PTL may present with rapidly growing mass, difficulty in swallowing, stridor, change in voice quality and/or pressure symptoms. With these symptoms and findings, they show some similarity to anaplastic thyroid cancers. It is detected as a solid mass that cannot be clearly distinguished with trachea or esophagus on physical examination. Salivary gland neoplasms, thyroglos- 
sal duct cyst, laryngocele, teratoma, dermoid cyst, thymic cyst, paraganglioma, neurinoma and lipomas should be considered in differential diagnosis.

Lapadat et al. have shown that most primary thyroid lymphomas develop on the chronic thyroiditis/Hashimoto thyroiditis pattern (4). Thyroid lymphoma should be considered in patients with Hashimoto thyroiditis when enlargement in the thyroid gland remains, despite the thyroxine replacement therapy. Hashimoto thyroiditis was found in two of our patients who underwent thyroidectomy. Besides, 30-40\% of the patients may present with hypothyroidism (5).

FNAB is sufficient for diagnosis when the samples are evaluated by an experienced cytologist. FNAB of the lesion reveals numerous large neoplastic cells with scant to moderate amount of cytoplasm, irregular nuclear contours and conspicuous nucleoli in a background of many small lymphocytes. In a study by Matsuzuka et al., among 83 patients who underwent FNAB, 65 patients (78.3\%) were diagnosed accurately and 10 patients (12\%) had borderline cytologic results (6). Thus, $90 \%$ of the patients with thyroid lymphoma were diagnosed or the diagnosis suspected based on fine needle aspiration biopsy. To confirm the diagnosis of lymphoma histologically and to determine the degree of malignancy, open biopsy taking 2-3 g tissue should be done for all cases. Only two of our patients could be diagnosed with fine needle aspiration biopsy (FNAB), and the other two patients were diagnosed after surgical excision.

It should not be forgotten that thyroid lymphomas may be accompanied by other primary neoplasms of the thyroid (papillary, follicular, anaplastic). For this reason, in addition to histopathological analysis, immunohistochemical staining with monoclonal antibodies should also be performed (7). One of our cases displayed a coexistence with papillary thyroid carcinoma. Immunophenotypically, neoplastic cells express CD20, CD79a, CD21 and CD35. They may be negative for CD5, CD10 and CD23 and positive or negative for $\mathrm{CD} 43$ and $\mathrm{CD} 11 \mathrm{C}$.

Due to contradictions in the surgical treatment of thyroid lymphomas, it should be differentiated from systemic lymphoma when diagnosed. According to studies from the Mayo Clinic, it is reported that disease-free survival and high cure rates are obtained with thyroidectomy and adjuvant RT (8). Today, it is stated that surgery should only be performed for histological diagnosis. Cervical-mediastinal RT should be the initial treatment choice in patients who have good prognosis and when the disease is limited to the thyroid. A study of 31 patients with primary thyroid MALT lymphoma has reported a 5-year survival rate of 90\% after receiving solely RT (9). RT and CT should be added in high grade lymphomas which display extracapsular extension (5). CHOP (cyclophosphamide, adriamycin, vincristine, prednisolone) regimen with Rituximab has shown to be the best combination therapy for disease-free survival (5). It is also recommended that pathological diagnosis should be ensured by FNAB and CT should be preferred as the initial treatment when recurrence or systemic disease exists. Adding Rituximab to the treatment regimens against CD20 surface antibody results very well. In our series, one of the patients who had received combined treatment had good prognosis. CHOP- Rituximab treatment usually causes neutropenic fever and the clinicians should be careful about this clinical manifestation. In our series, one patient died from neutropenic fever. Grade of the tumor also has great importance in prognosis. Ten-year survival rate for low-grade lymphoma is $75 \%$, and for the high-grade disease, 5-year survival rate is less than 50\% (10). Besides, older age and extracapsular extension have a negative effect on the prognosis. All of our patients received CT and RT. Two patients underwent surgery for diagnosis and one patient underwent surgery due to pressure symptoms. All patients except one have been followed up without any evidence of disease.

\section{CONCLUSION}

It is challenging to diagnose primary thyroid lymphomas because of their rare occurrence. For this reason, it should be kept in mind that patients with chronic lymphocytic thyroiditis should be evaluated carefully when they have a rapidly growing thyroid gland or cervical LAP. According to the literature and our clinical experience, we can state that RT is the most adequate treatment for patients especially with low grade lymphoma, and $\mathrm{CT}$ should be added to the treatment of the patients with high grade lymphoma.

Informed Consent: Informed consent was obtained from both patients. Consents were also obtained to perform scientific studies.

Peer-review: Externally peer-reviewed.

Author Contributions: Concept - N.A., T.A., M.H.; Design - N.A., T.A., M.H.; Supervision - N.A., T.A., M.H.; Resource - N.A., T.A., M.H.; Materials - N.A., T.A., M.H.; Data Collection and/or Processing - N.A., T.A., M.H.; Analysis and/or Interpretation - N.A., T.A., M.H.; Literature Search - N.A., T.A., M.H.; Writing Manuscript - N.A., T.A., M.H.; Critical Reviews - N.A., T.A., M.H.

Conflict of Interest: No conflict of interest was declared by the authors.

Financial Disclosure: The authors declared that this study has received no financial support.

\section{REFERENCES}

1. Xie Y, Liu W, Liu Y, Wang W, Wang M, Liu H, et al. Diagnosis and clinical analysis of primary thyroid lymphoma. Acta Academiae Medicinae Sinicae 2017; 39: 377-82.

2. Zeppa P, Vitale M. Fine needle cytology and flowcytometry in Hashimoto thyroiditis and primary thyroid lymphoma. Acta Cytol 2014; 58: 318. [CrossRef]

3. HacıyanII IN, Erkan N, Yorukoglu K, Sagol O, Harmancioğlu O. Primary non Hodgkin's T-cell lymphoma of the thyroid gland complicating Hashimoto's thyroiditis: case report. Thyroid 2010; 10: 717-20. [CrossRef] 
Lapadat R, Nam MW, Mehrotra S, Velankar M, Pambuccian SE. Mulberry cells in the thyroid: warthin-finkeldey-like cells in hashimoto thyroiditis-associated lymphoma. Diagn Cytopathol 2017; 45: 212-6. [CrossRef]

5. Regalbuto C, Frasca F, Pollegritti G, Malandrino P, Marturano I, Di Carlo I, et al. Update on thyroid cancer treatment. Future Onc 2012; 8: 1331-48. [CrossRef]

6. Matsuzuka F, Miyauchi A, Katayama S, Narabayashi I, Ikeda H, Kuma $K$, et al Clinical aspects of primary thyroid lymphoma: diagnosis and treatment based on our experience of 119 cases. Thyroid 1993; 3: 93-9. [CrossRef]

7. Ahmed OI, Salih ZT. Dual malignancy in a thyroid; papillary thyroid carcinoma and small lymphocytic lymphoma; a report of a case with a cyto-histologic correlation. Diagn Cytopathol 2017; 45: 851-6.

[CrossRef]
8. Ansell SM, Grant CS, Habermann TM. Primary thyroid lymphoma. Semin Oncol 1999; 26: 316-23.

9. Hirokawa M, Kudo T, Ota H, Suzuki A, Kobayashi K, Miyauchi A. Preoperative diagnostic algorithm of primary thyroid lymphoma using ultrasound, aspiration cytology, and flow cytometry. Endocr J 2017; 64: 859-65. [CrossRef]

10. Hengjeerajarus N, Klaisuwan T, Norasetthada L, Kosachunhanun N. Mucosa-associated lymphoid tissue lymphoma with large cell transformation on the background of Hashimoto's thyroiditis: a case report and review literature. J Med Assoc Thai 2015; 98: 514-9.

\section{Primer tiroid lenfomasına yaklaşım: Olgu serisi}

Nihan Acar ${ }^{1}$, Turan Acar ${ }^{1}$, Arzu Avcl ${ }^{2}$, Mehmet Haciyanlı ${ }^{1}$

${ }^{1}$ İzmir Katip Çelebi Üniversitesi, Atatürk Eğitim ve Araştırma Hastanesi, Genel Cerrahi Kliniği, İzmir, Türkiye

${ }^{2}$ İzmir Katip Çelebi Üniversitesi, Atatürk Eğitim ve Araştırma Hastanesi, Patoloji Kliniği, İzmir, Türkiye

\section{ÖZET}

Primer tiroid lenfomaları nadir görülen bir kanserdir. Sıklıkla MALT (Mucosa Associated Lenfoid Tissue) ve diffüz B hücreli non-hodgkin lenfomalar görülür. Yaşlılarda ve özellikle kadınlarda daha sık rastlanır. Boyunda aniden büyüyen kitle olarak bulgu verirler. Biz de bu yazımızda tiroid lenfoması tanısı almış dört hastamızın retrospektif olarak dosyalarını tarayarak, epidemiyolojik özelliklerini, teşhislerini, tedavi ve prognostik belirteçlerini sunmayı amaçladık. İkisi erkek ve ikisi kadın, primer tiroid lenfoma tanılı, dört hastamızın ortalama yaşı 63,75 ( 51-74 )'tir. Hastaların ortak şikayetleri, boyunda aniden ortaya çıkan kitle. İki hastanın tanısı ince iğne aspirasyon biyopsisi (iïAB) ile diğer iki hastanın tanısı ise cerrah eksizyon ile konuldu. Dört hastaya da kemoterapi ve radyoterapi verildi. Bir hasta takibinin ikinci yılında eksitus olurken, diğer üç hasta halen takibimizde. Primer tiroid lenfomaları agresif seyirli tümör değildirler ve en etkili tedavi radyoterapidir.

Anahtar Kelimeler: Tiroid, lenfoma, MALT, non-hodgkin

Doi: $10.5578 /$ turkjsurg.4132 